\title{
Modern Principles of Educational Process at the Secondary Vocational and Professional Training
}

\author{
Akhmat Marasulov \\ Doctor of Engineering, Professor, University "Miras", Shymkent \\ Amangeldi Saipov \\ Doctor of Education, Associate Professor, M. Auezov South Kazakhstan State University, Shymkent \\ Email: bauka1953@bk.ru, amabhajy@gmail.com \\ Danebek Poshayev \\ Candidate of Pedagogical Sciences, Associate Professor, M. Auezov South Kazakhstan State University, Shymkent \\ Email: dimash_p@mail.ru \\ Yussubaly Kamalov \\ Candidate of Pedagogical Sciences, Associate Professor, M. Auezov South Kazakhstan State University, Shymkent \\ Email: iusubaly@mail.ru \\ Ainagul Uzakhova \\ Candidate of Pedagogical Sciences, Senior Teacher, M. Auezov South Kazakhstan State University, Shymkent \\ Email: aman.egember@mail.ru

\section{Bastarbek Karsybayev} \\ Candidate of Pedagogical Sciences, Head of Department, M. Auezov South Kazakhstan State University, Shymkent \\ Email: bauka1953@bk.ru, amabhajy@gmail.com \\ Assiya Orazova \\ Candidate of Pedagogical Sciences, Senior Teacher, Shymkent University \\ Email: birjan_99@mail.ru \\ Aidai Baibatshaeva \\ Candidate of Pedagogical Sciences, Head of Department, M. Auezov South Kazakhstan State University, Shymkent \\ Email: aidai_67_13@ mail.ru
}

Doi:10.5901/mjss.2015.v6n1s2p72

Abstract

A humanitarian and professional educational environment, computer-information technology of educational institution for the professional education are formed on the basis for formation of links between studied general education, humanitarian, social, economic, technical disciplines and composing criteria - characteristics of educating-behavioral pedagogic education, coordinate components of logical-meaning model of an individual, structure-logical activity scheme of a specialist, criteria for the pedagogical system assessment of efficiency.

Keywords: educational institution, humanitarian, professional educational environment, educating-behavioral pedagogical education, logical-meaning model of an individual, a specialist's activity model, assessment of efficiency.

\section{Introduction}

One of the fundamental tasks of the Republic education is assurance of the educational process quality in the educational institutions including secondary vocational, professional education.

Currently we deal with solution of a number of technological and social problems. Technological problems have methodological, theoretical, and organizational character. Social problems are related to the contradictions reflected in the professional activity of teachers. Without loss of merits of currently used approaches, methods, and ways for realization of the pointed problems it should be noted that they are in a greater or lesser degree developed and realized 
independently, and not grouped in a single interrelated complex. To our opinion, it is connected with the lack of related information-technological base providing such unification. Therefore, determination of leading scientific approaches to the management by sustained development of educational process in the educational institution of secondary vocational and professional training is of special relevance. Scientific study of the education should assist to the complex solution of technological and social problems and realization of the modern social demands.

\section{Methods}

Therefore, the problem on development and application of special technology, considering specified conditions, able to provide high quality of the educational process in the educational institution of secondary vocational and professional training, is very topical.

Modern educational process is complicated, many-sided, requires serious-minded study and permanent development. But, despite great strides in the training content improvement, activated the educational process at large, quality of the training and education of trainees in the educational institutions leave much to be desired. Hence we cannot deny availability of serious disadvantages in theory and practice of the training (Marasulov, Nazarov, Ostroverh, 2007).

To our opinion, such condition is related to the following problems of the educational institutions:

Firstly, the educational institutions have no technology of organization, conduction of activity of the educational institutions and its assessment based on complex determination and formation of educating-behavioral pedagogical education of trainees, trainees as individuals, as subjects of the educational process, teachers as subjects of the educational environment formation;

Secondly, the educational institutions have no special technologies for formation of humanitarian and professional educational environments;

Thirdly, the educational institutions have no technology for enhancement of pedagogical system;

The fourth, absence of computer-information technology of organization and conduction of the educational process;

Considering our experience and as it is appeared for us, for successful exclusion of specified disadvantages and achievement of required educational qualities, development of the educational processes of educational institutions should be considered from realization positions of generalized scheme for development principles on trainees' trainingcognitive abilities and teachers' educational activities, their problems and major tasks, formalization and specification of solutions of these tasks. At that, formation and development of the trainees' training-cognitive abilities should be determined by conditions and structure of the educational processes' subject formation process. Formation and development of the teachers' educational activities should be determined by a system on description and assessment of the educational environment. The educational processes of educational institutions should be carried out on the ground of educational-methodic complex. Its didactic functions favor to the effective learning and consequent consideration of objective psychologically pedagogical laws of the trainees' educational-cognitive activity and teachers' educational activities. Structural efficiency of the educational processes of educational institutions should be determined by realization efficiency of coordinate components of a logical-meaning model of an individual. Efficiency of the educational institutions' pedagogical system should be determined by realization efficiency of structural components of the pedagogical system development level integration indicator.

The outreach-behavioral pedagogic education as a social science, as a discipline should be studied through interdisciplinary integration of general education, social, economic and humanitarian, technical and engineering disciplines, considering solution of a problem to provide integration of training, education and development of trainees (Marasulov, 2008). Taking into account all above mentioned, Scheme No. 1 presents aspects of training, education and development of a student, individual, their common links in the outreach- behavioral pedagogic education.

Two-based components of an individual are well-known. These are need-motivation sphere and cognitive sphere. The logical-meaning model of an individual is considered as a psychological basis to determine developing educational technologies. Depending on the orientation for the main components, the logical-meaning model of an individual separates the following:

- socio-professional education as a direction component;

- context education as a professional-educational component;

- cognitive acquisition as a cognitive component;

- corporate co-training as a communicative component;

- self-regulating learning and self-directed education as a regulative component.

On the ground of this fact, Figure 1 shows the logical-meaning model of an individual. A system of intra-disciplinary 
links and interdisciplinary integrations is formed considering links of general education, humanitarian, social economic disciplines with component criteria, characteristics of the outreach-behavioral pedagogic education, coordinate components of individual's logical-meaning model and two-based components. Levels of the trainees' outreachbehavioral pedagogic education and their formation as individuals are determined on the ground of corresponding experttest evaluations. Humanitarian educational environment is formed in a result of the above mentioned realization.

Construction of a structural-logic scheme of a specialist's activity has significant meaning in formation of the educational content. In construction of the structural-logic scheme of a specialist's activity, we were supported by approach, including a specialist's skills:

Firstly, correctly detect state of the considered subject of education, training or object of study (maintenance, restoration);

Secondly, correctly determine reasons of a subject or object's state deviation from the norm;

Thirdly, correctly determine consequences (complications) of the deviation from the norm;

The fourth, correctly make the diagnosis of a subject or object's state;

Fifthly, correctly influence with a view to normalize a subject or object's state;

Sixthly, correctly assess effects;

Seventhly, correctly determine preventive measures of various deviations from the norm and realize them.

In construction of the intra-disciplinary links and interdisciplinary integrations' system, we based on the following. For example, let's suppose that a system of disciplines to train a specialist was formulated. Each discipline consists of sections, which in their turn are separated on corresponding themes. Each of these themes contains its own topical points. These topical points are separated into 4 units. The first unit is A, these are topical points studied at the moment. The second unit is $B$, these are topical points characterizing previous link. The third unit is $C$, these are topical points characterizing consequent link. The fourth unit id $\mathrm{D}$, these are topical points characterizing interdisciplinary integrations.

A functional map for a profession (specialty) is determined by the basic key purpose and list of main functions. At that, it should follow the next normative sequence:

(1) - determination of the basic key purpose of a profession (specialty) by the state mandatory educational standard;

(2) - determination on the ground of (1) list of the main functions by the state mandatory educational standard;

(3) - determination on the ground of (2), formation of corresponding units $A, B, C, D$ for each of the main functions.

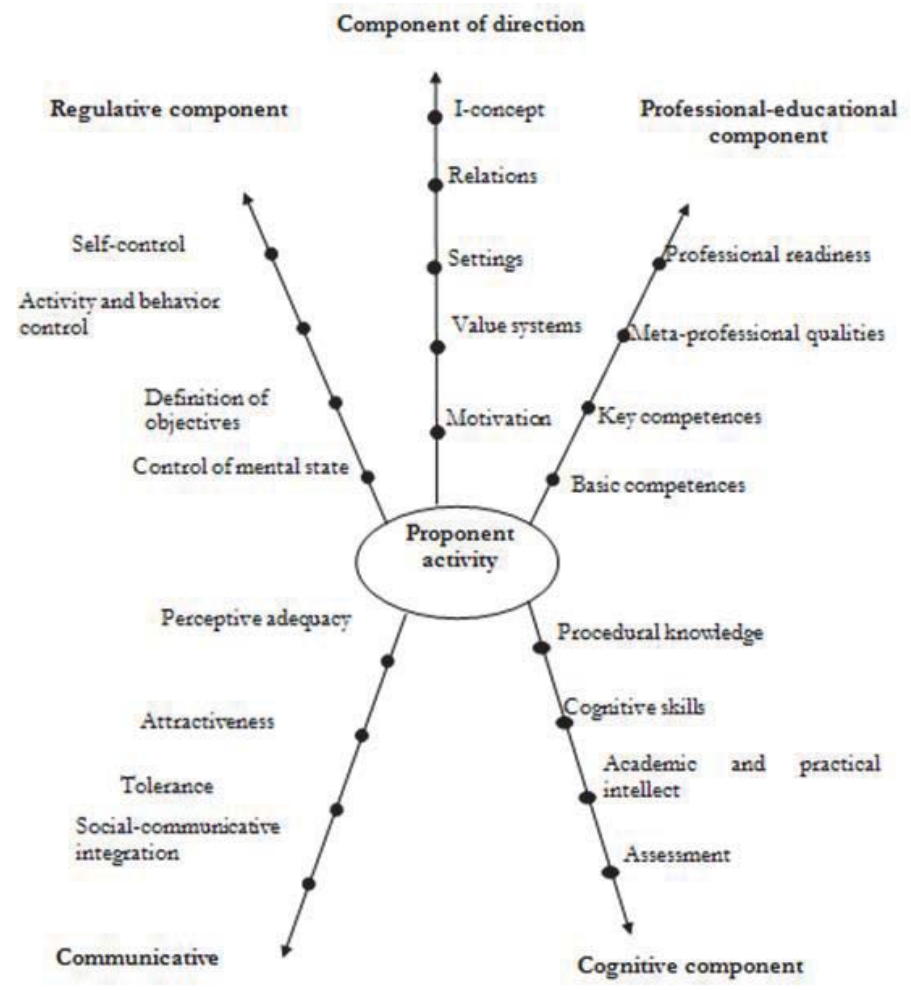

Fig.1. Logical-meaning model 


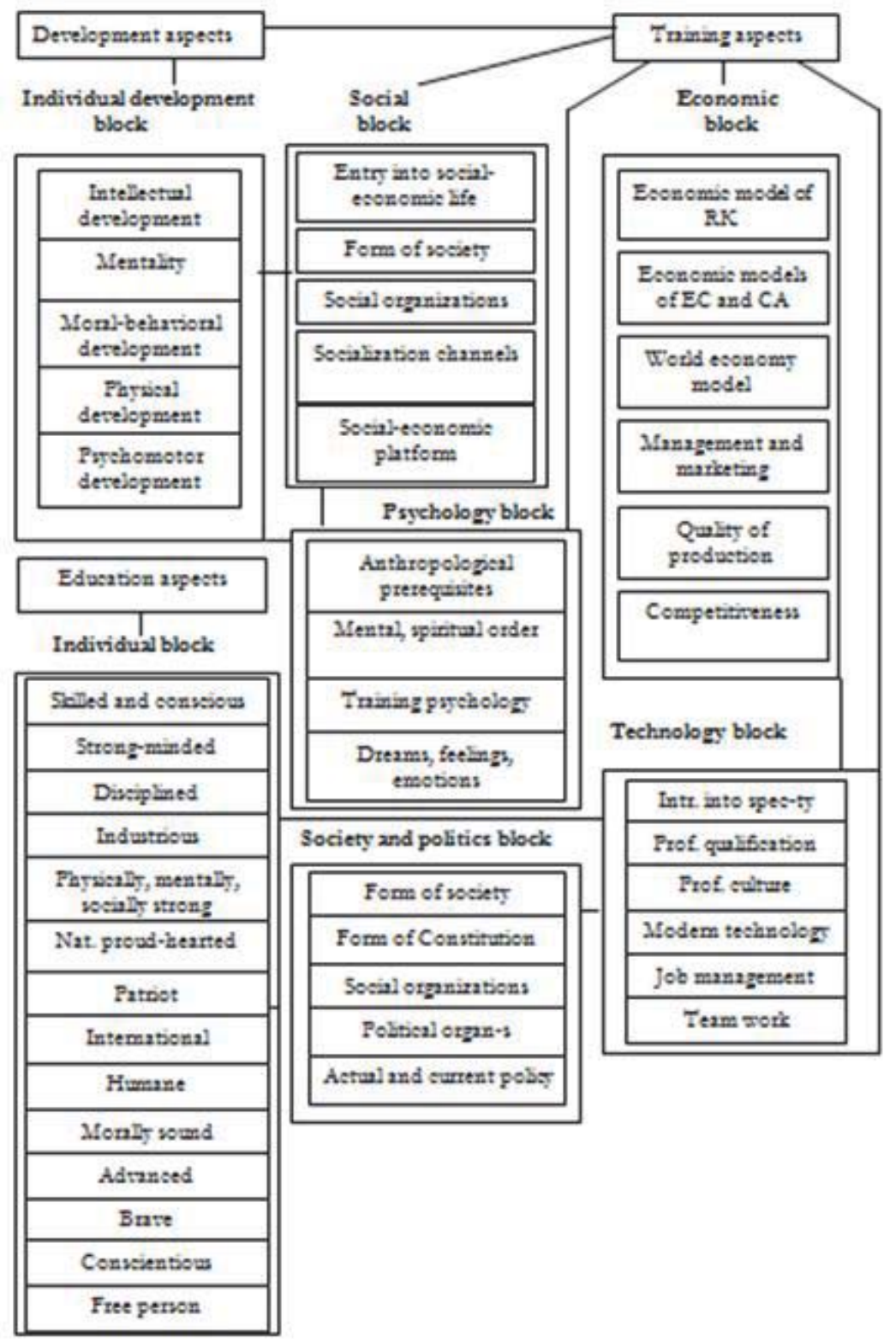

Scheme No.1 Aspects of training, education and development of a student's individuality and their general links in the behavioral educating-pedagogical education

\section{Results}

In a result, considering corresponding technological provision of a specialty, the general structure of intra-disciplinary links and interdisciplinary integrations is composed. The general structure of intra-disciplinary links and interdisciplinary integrations is divided by 1-7 activity kinds of the above mentioned structural-logic scheme of a specialist's activity. Relevant skills are formed on their bases. Relevant knowledge is formed by each of the skills. Knowledge domains are formed by each knowledge. Reference conspectus are formed on the ground of received circles of skills, knowledge, knowledge domains.

To evaluate efficiency of the pedagogical system in the educational institutions, the following criteria are used:

- transfer degree of socially significant purpose of the education institutions into the cause of pedagogical and educational activity;

- adequacy of the purpose's content; 
- level of collective management;

- $\quad$ possession degree of teachers by interiorization technology of the purpose, content of the educational material and pedagogical communications;

- correspondence of pedagogical communications to the studied material;

- teachers' qualification level;

- quality correspondence of trainees' knowledge and education level to the requirements of state compulsory educational standard;

- direction of energy resources for exploratory and practical activity;

- correspondence of trainees' psychological-physiological conditions to the requirements of pedagogical system, are they purposeful and able-bodied (know who they want to be, possess by skills of educational activity, selfeducation, self-control, detect deviation from the purpose, correct activity structure).

Professional educational environment is formed in a result of the above mentioned realization.

The general structural-functional scheme of computer-information management system by secondary vocational, professional education institutions educational processes forms the basis of computer-information technology on organization and performance of the educational processes, considering complex realization of the above mentioned technological and social problems. This scheme is presented in Scheme No. 2.

According to the results of preliminary experimental research, application of the proposed by us approach will provide the following:

1. Creation of foundations for effective realization of the secondary vocational, professional education institutions' technologization and informatization problems.

2. Provision of conditions for growth of professional qualification and mastery of the secondary vocational, professional education institutions' administrative and pedagogical staff.

3. Provision of system on the real technologically controlled quality for training of specialists.

4. Improvement of the secondary vocational, professional education institutions' activity based on creation of computer-information basis of its management, creation of environment for information-technological interaction as a working environment.

5. Creation of computer-information technology for the secondary vocational, professional education institutions' educational processes organization and performance.

\begin{tabular}{|c|c|c|c|c|c|c|}
\hline \multicolumn{2}{|c|}{$\begin{array}{l}\text { Information-analytical } \\
\text { management network } \\
\text { by the educational } \\
\text { institution educational } \\
\text { process }\end{array}$} & \multicolumn{3}{|c|}{$\begin{array}{l}\text { Information-analytical } \\
\text { network of the system } \\
\text { for staged increase in } \\
\text { quality of knowledge, } \\
\text { skills, habits of trainees }\end{array}$} & \multicolumn{2}{|c|}{$\begin{array}{l}\text { Generalized technolog: for } \\
\text { construction, control and } \\
\text { assessment of the } \\
\text { pedagogical system and } \\
\text { educational process } \\
\text { efficiency }\end{array}$} \\
\hline \multicolumn{2}{|c|}{$\begin{array}{l}\text { Automation-equipped } \\
\text { working places of } \\
\text { administrative- } \\
\text { pedagogical staff }\end{array}$} & \multicolumn{3}{|c|}{$\begin{array}{l}\text { Generalized information- } \\
\text { analyticll network of the } \\
\text { educational institution } \\
\text { training-methodical } \\
\text { complex }\end{array}$} & \multicolumn{2}{|c|}{$\begin{array}{l}\text { Scientific-methodical ware } \\
\text { of the educational } \\
\text { institution methodical } \\
\text { service activity }\end{array}$} \\
\hline \multicolumn{3}{|c|}{$\begin{array}{l}\text { Computer-information } \\
\text { management system by the } \\
\text { educational institution } \\
\text { educational system }\end{array}$} & \multicolumn{2}{|c|}{$\begin{array}{l}\text { System of expert-test } \\
\text { questionnaire and } \\
\text { scores }\end{array}$} & \multicolumn{2}{|c|}{$\begin{array}{l}\text { Psychological- } \\
\text { pedagogical service }\end{array}$} \\
\hline \multicolumn{2}{|c|}{$\begin{array}{l}\text { Information-logical } \\
\text { system for } \\
\text { determination and } \\
\text { formation of trainees } \\
\text { as subjects of the } \\
\text { educational process }\end{array}$} & \multicolumn{2}{|c|}{$\begin{array}{l}\text { Information-logical } \\
\text { system for determination } \\
\text { of spicitual-educating } \\
\text { edveation of trainees and } \\
\text { their formation as } \\
\text { individuals }\end{array}$} & & \multicolumn{2}{|c|}{$\begin{array}{l}\text { Information-logical system for } \\
\text { determination and formation } \\
\text { of humanitarian and } \\
\text { professional edveational } \\
\text { environments of the } \\
\text { educational institution }\end{array}$} \\
\hline $\begin{array}{l}\text { Base of } \\
\text { informatio } \\
\text { n-resource } \\
\text { center }\end{array}$ & $\begin{array}{l}\text { Model of } \\
\text { training and } \\
\text { actirity of a } \\
\text { specialist }\end{array}$ & & $\begin{array}{l}\text { System of intra- } \\
\text { discipline link } \\
\text { and inter-subject } \\
\text { integration }\end{array}$ & $\begin{array}{l}\text { Plannin } \\
\text { calenda }\end{array}$ & $\begin{array}{l}\text { Knowiedg } \\
\text { e, skills, } \\
\text { habits, } \\
\text { subject } \\
\text { fields }\end{array}$ & $\begin{array}{l}\text { Refere } \\
\text { nce } \\
\text { compe } \\
\text { ndia }\end{array}$ \\
\hline
\end{tabular}

Scheme No. 2. General structural-functional scheme of computer-information system for management by the educational process of the educational institutions of secondary vocational and professional training 


\section{References}

Marasulov, A. F., Nazarov, B. B., Ostroverh, I. L. (2007). The work technology of the specialized secondary, professional educational establishment. Tashkent: Pedagogical education.

Marasulov, A. F. (2008). To the level estimation system construction of whose obtaining ecclesiastical education and their formation as the person in educational establishment. Tashkent: Educational technologies.

Marasulov, A.F. (2010). Special and vocational education institution training process of theoretical and methodological support, educational system and the implementation of technology. Tashkent: Tashkent Chemical Technological Institute.

Poshayev, D.K., Saipov, A., Adyrbekova, G. (2012). Arnayi penderli okytu edistemesi. Astana: Oku kuraly.

Poshayev, D.K. (2011). Gylymi-pedagogikalyk zertteu negizderi. Oku kuraly. Shymkent: Nurly beine. 